\title{
Understanding the Linkages and Importance of Urban Greenspaces for Achieving Sustainable Development Goals 2030
}

\author{
Md. Badrul Hyder ${ }^{1} \&$ Tareq Zahirul Haque ${ }^{1}$ \\ ${ }^{1}$ Ph.D. researcher, School of Global, Urban and Social Studies, RMIT University, Melbourne, Australia \\ Correspondence: Md. Badrul Hyder, School of Global, Urban and Social Studies, RMIT University, Melbourne, \\ Australia. Tel: 61-04-7619-1037. E-mail: md.badrul.hyder@student.rmit.edu.au
}

Received: January 3, 2022

Accepted: February 8, $2022 \quad$ Online Published: February 14, 2022

doi:10.5539/jsd.v15n2p144

URL: https://doi.org/10.5539/jsd.v15n2p144

\begin{abstract}
Urban greenspaces have an immense contribution to the social, environmental, and economic spectrums of sustainable development. These three spectrums are also the foundation of Sustainable Development Goals (SDGs) 2030. Thus, this interdependence nature offers an opportunity to study the linkages between urban greenspaces and SDGs targets for acknowledging the importance of urban greenspaces for achieving SDGs 2030. To understand the linkages, the study follows a qualitative study approach. In the approach, a convenient systematic literature search technique has been employed to define urban greenspaces and identify empirical evidence on greenspaces' contribution to different SDG targets. For ensuring the authenticity and validity of the findings, the study includes only peer-reviewed articles in the systematic technique. Results suggest an immediate association between urban greenspaces and SDG target 11.7, which emphasizes explicitly the provision (quality, quantity, and accessibility) of urban parks and playgrounds for the physical and mental wellbeing of urban citizens, typically the social spectrum of sustainable development. In addition to the apparent link, fourteen more underlying connections have been identified where urban greenspaces can contribute to fourteen different SDG targets. These underlying connections acknowledge the importance of urban greenspaces for achieving SDGs 2030.
\end{abstract}

Keywords: contribution, importance, linkages, SDGs, urban greenspace

\section{Introduction}

The contribution of urban greenspaces to the social, environmental, and economic spectrum of sustainable development is well established and acknowledged by academics and non-academics (Benton-Short, Keeley \& Rowland, 2017; Cohen-Cline, Turkheimer \& Duncan, 2015; Davies, Edmondson, Heinemeyer, Leake \& Gaston, 2011; Hartig, Mitchell, de Vries \& Frumkin, 2014; Hunter et al., 2015). However, the prevailing worldwide urbanization is posing a threat to urban greenspaces and their contributions. Realizing the negative consequences of urbanization and the importance of greenspaces, the former United Nations (UN) Secretary-General, Ban-Kimoon, in his speech at the High-Level Delegation of Mayors and Regional Authorities in New York City, has acknowledged the importance of urban areas for achieving sustainability by stating that "our struggle for global sustainability will be lost or won in cities" (United Nations [UN], 2012). In the statement, he tries to capture both the positive and negative impacts of urbanization. Three years later in 2015, the UN summit declares the Sustainable Development Goals (SDGs) 2030 and provides a much stronger emphasis on cities than the Millennium Development Goals (MDGs). Goal 11 of SDGs: Making cities and human settlements inclusive, safe, resilient, and sustainable particularly refers to urban development and target 11.7 of goal 11 explicitly aims to develop urban greenspaces. The target aims to provide universal access to safe, inclusive, and accessible, green, and public spaces, in particular for women and children, older persons, and persons with disabilities by 2030 (UN, 2015). Thus, delivering and managing urban greenspaces for promoting healthy living becomes a multi-sectoral global priority and international and national agenda (Knuiman et al., 2014). But the question arises: what is urban greenspace, and what types of greenspaces does the target 11.7 indicate? In a general sense, urban public parks and playgrounds are the center of the target 11.7 because they are freely accessible, and they have positive impact on social, physical, and mental wellbeing of urban residents.

Though the SDG target 11.7 gives importance to the provision (quantity, quality, and accessibility) of urban greenspaces for residents' physical and mental wellbeing, the greatest benefits of having urban greenspaces are not limited to the physical and mental wellbeing of residents only because urban greenspaces also contribute to 
the economic and environmental spectrums of urban development. Therefore, the question is whether achieving the target 11.7 is a standalone success or will work as a catalyst for achieving other targets of SDGs. Focusing on the question, the paper tries to identify the linkages between urban greenspaces and SDGs targets by identifying the evidence of the contribution of urban greenspaces to different SDG targets. In responding the question, the study will realize the importance of greenspaces for achieving SDGs 2030.

\section{Methods and Techniques}

The main objective of the study is to acknowledge the importance of urban greenspaces for achieving SDGs 2030 by identifying the contribution of different urban greenspaces to SDG targets. The study takes a qualitative research approach. In the approach, a convenient systematic literature search technique is employed in order to define urban greenspaces and identify empirical evidence on their contribution to different SDG targets. In the first step, the term "definition of urban greenspace" and "typology of urban greenspace" were searched using Google Scholar. The search result was limited to only peer-reviewed English language articles published since 2000. Initially, we chose 25 articles for the definition of urban greenspace and 12 articles for the typology of urban greenspace by assessing the title and abstract. Later, skimming through the main text and eliminating the irrelevant and repeated articles, 14 articles for the definition of urban greenspace and 7 articles for the typology of urban greenspaces were selected and studied thoroughly for making a comprehensive understanding of urban greenspaces for the study. In the second stage, the term "importance of urban greenspaces for sustainable development" was searched using Google Scholar. The search result was limited to only peer-reviewed English language articles published since 2000. After skimming more than dozens of articles, we selected 12 articles because they comprehensively describe the benefits of urban greenspaces. These articles were carefully studied and used for refining the understanding and influence of urban greenspaces in the social, economic, and environmental spectrums of sustainable development. Both stages provide the theoretical foundation of urban greenspaces, types of urban greenspaces, and their contribution to different spectrums of sustainability development. In the final step, since the focus of the paper is to establish the linkages of urban greenspaces and the SDGs 2030, corresponding literature was searched in Google Scholar for gathering evidence or examples. For example, the term 'contribution of urban greenspace to reduce poverty or hunger' for SDG goals 1 and 2, 'contribution of urban greenspace to good health and wellbeing' for SDG goal 3, and so on. The search was limited to peer-reviewed articles. Once the empirical evidence is identified in an article, the search and review of the articles were ended for the specific SDGs goal or targets. The convenient nature of systematic review helps to allow a wide range of information for assimilation, avoid biases, and provide more accurate and reliable conclusions (Akobeng, 2005; Victor, 2008). The paper however does not provide the detailed goals and targets of SDGs 2030 as it is readily available.

\section{Results}

\subsection{Urban Greenspace}

Academic scholars use both the term "open space" and public and/or urban "greenspace" when referring to urban greenspace in their research (Barbosa et al., 2007; Griffith, 2000; Kabisch \& Haase, 2014). Depending on the academic discipline, the use of the term "open space" and "greenspace" differs. For example, ecological studies often use greenspace as urban parks or tree canopy (Ikin et al., 2013), while urban planning studies use publicly accessible vegetated open space as greenspace (Lachowycz \& Jones, 2013; Tavernia \& Reed, 2009). But there is no strict pattern of how various disciplines refer to urban greenspace. For the lack of consensus on the separation between urban open space and greenspace, academic literature exacerbates the complexity further (Taylor \& Hochuli, 2017). However, for clarity and a better understanding of the meaning of urban greenspace, some scholars have attempted to define urban greenspace more explicitly. According to Baycan-Levent, Leeuwen, Rodenburg and Nijkamp (2002), urban greenspace is public or private urban areas primarily covered by vegetation. Wilson and Hughes (2011) define urban greenspace as covering the vast diversity of greenspace found within towns and cities, both publicly and privately owned. Jim and Chen (2003) refers to urban greenspace as outdoor places with vegetation and semi-natural areas. For Fam et al. (2008), urban greenspace is all vegetated areas in an urban area, including trees, shrubs, and grasses. Yusof (2012) denotes urban greenspace as an urban area or land covered with vegetation or water. On the other hand, city authorities tend to define urban public greenspace as publicly owned lands that are publicly accessible, and the purposes of these lands are for recreation, sports, natural conservation, and public gathering, e.g. parks, gardens, reserves, and public squares (Low, Taplin \& Scheld 2009; Woolley, 2003). And according to public policy guides, urban greenspaces are parks, gardens, and amenity areas under public recreation or woodlands and nature reserves that are managed for conservation (Wilson \& Hughes, 2011). Therefore, there is no single definition for urban greenspace. Individuals have defined it based on their purpose, discipline, or context. Thus, researchers often provide example of what greenspace means instead of definition in their study for clarity. 


\subsection{Types of Urban Greenspace}

Considering the basic distinction, academics and city authorities have distinguished different types of greenspaces. For example, academics Herzele and Wiederman (2003) have presented six types of urban greenspace depending on size. Baycan-Levent, Vreeker and Nijkamp (2004) have classified urban greenspace into sixteen types under five values (ecological, social, economic, planning, and multi-functional values). Fuwape and Onyekwelu (2011) and Mensah (2014) have identified seven types of greenspace. Among different academics, Swanwick, Dunnett, and Woolley (2003) have come up with a very elementary description for defining urban greenspace by distinguishing an urban area into two categories: "greenspace" and "grey space" (see figure 1).

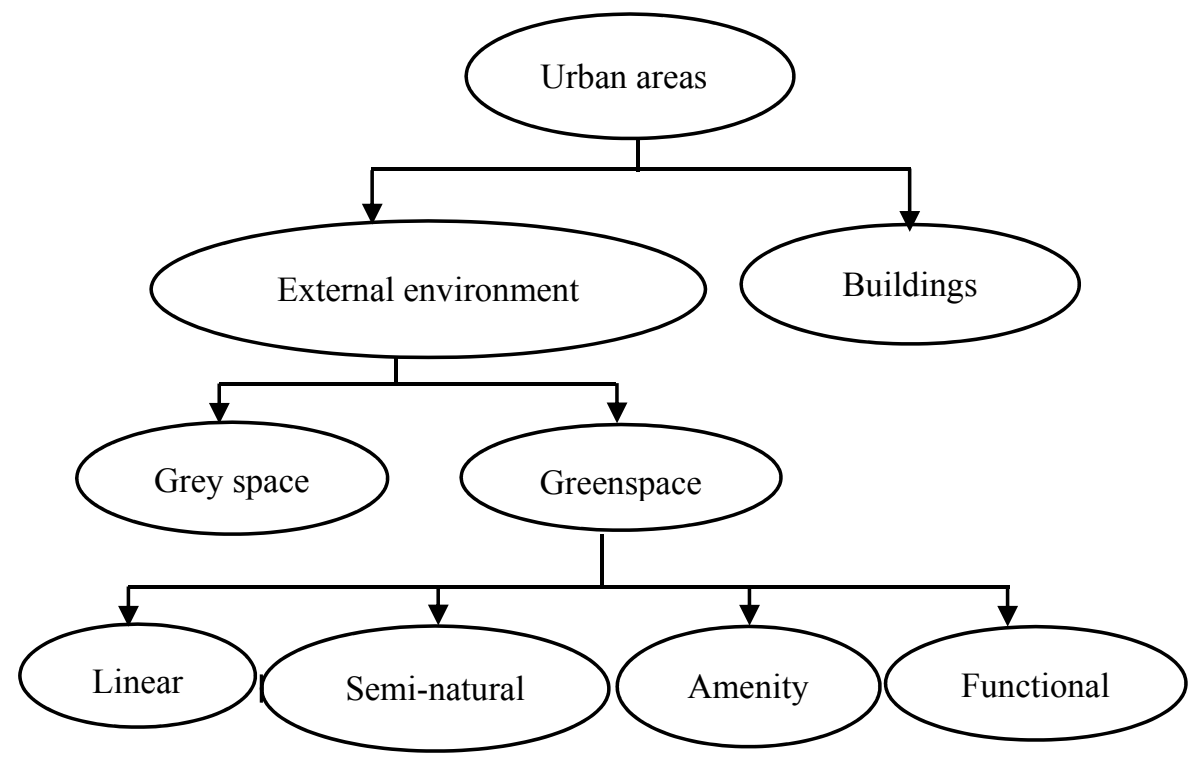

Figure 1. Greenspaces in urban landscape (Swanwick et al., 2003)

The greenspace consists of unsealed, permeable, soft surfaces such as soil grass, shrubs, and trees, and they may either be linear, semi-natural, functional or amenity in nature. The grey space is the land that is usually sealed, impermeable, and has a hard surface such as concrete, paving, or tarmac, and they are either functional grey space (e.g., roads, pavements, car parks) or civic grey spaces (town squares, plazas, and esplanades). From this lens, urban greenspace is the subset of urban open spaces and is limited to the vegetative part of the urban environment. City authorities commonly use a four-level hierarchy to classify publicly owned and managed urban greenspaces (Kohout \& Kopp, 2020; Swanwick et al., 2003). These are City/Metropolitan Parks, District Parks, Neighborhood Parks, and Local Parks. They only consider the public parks as urban public greenspaces and disregard other types like productive greenspace or wetlands. Hence, city authorities often eliminate some useful urban greenspaces in their policy and strategy like private greenspaces, small green lots, and linear greenspaces in transport corridors. 
Table 1. A typology of urban greenspace

\begin{tabular}{|c|c|c|}
\hline \multicolumn{3}{|c|}{ Types of urban greenspaces } \\
\hline Main type & Sub-class I & Sub-class II \\
\hline \multirow{7}{*}{$\begin{array}{l}\text { Amenity } \\
\text { greenspace }\end{array}$} & \multirow{4}{*}{ Recreational greenspaces } & Parks and gardens \\
\hline & & Informal recreational areas \\
\hline & & Outdoor sports areas \\
\hline & & Play areas \\
\hline & \multirow{2}{*}{ Incidental greenspace } & Housing greenspace \\
\hline & & Other incidental greenspaces \\
\hline & Private greenspace & Domestic garden \\
\hline \multirow{7}{*}{$\begin{array}{l}\text { Functional } \\
\text { greenspace }\end{array}$} & \multirow{3}{*}{ Productive greenspace } & Remnant farmlands \\
\hline & & City farms \\
\hline & & Allotments \\
\hline & \multirow{2}{*}{ Burial grounds } & Cemeteries \\
\hline & & Churchyards \\
\hline & \multirow{2}{*}{ Institutional grounds } & School grounds \\
\hline & & Other institutional grounds \\
\hline \multirow{8}{*}{$\begin{array}{l}\text { Semi-natural } \\
\text { greenspace }\end{array}$} & \multirow{2}{*}{ Wetlands } & Open/running water \\
\hline & & Marsh fens \\
\hline & \multirow{3}{*}{ Woodlands } & Deciduous woodland \\
\hline & & Coniferous woodland \\
\hline & & Mixed woodland \\
\hline & \multirow{3}{*}{ Other habitats } & Moorland \\
\hline & & Grassland \\
\hline & & Disturbed ground \\
\hline \multirow[t]{2}{*}{ Linear greenspace } & & $\begin{array}{l}\text { River and canal banks, Transport corridors } \\
\text { (road, rail, cycleways, and walking routes) }\end{array}$ \\
\hline & & Other linear feature (cliff) \\
\hline
\end{tabular}

Source: Adopted by authors from Dunnett, Swanwick \& Woolley (2002)

However, none of the typologies of urban greenspace is more detailed than Dunnett et al. (2002) provided urban greenspace typology as seen in the above table (table 1). In their comprehensive typology, greenspace ranges from amenity to functional to semi-natural, including linear ones. They try to cover all kinds of urban greenspace in their categories to avoid the risk of eliminating any valuable urban greenspace.

\subsection{Contributions of Urban Greenspace to Social, Economic, and Environmental Spectrum}

The contribution of greenspaces to the social, economic, and environmental spectrum of sustainable development is immense. In the social spectrum, urban greenspaces contribute to recreation, aesthetics, physical and psychological wellbeing, social interaction, community livability, and education (Kothencz, Kolcsár, CabreraBarona \& Szilassi, 2017; Mukherjee \& Takara, 2018). These contributions are associated with the health benefits of urban citizens including the elderly and children (Kabisch, van den Bosch \& Lafortezza, 2017). Urban greenspaces also contribute to cultural life and social justice by providing venues for local festivals and creating opportunities for people of all ages to interact (Scottish Executive, 2001). Social interaction enhances social cohesion and resilience through community engagement and shared experiences. In the economic spectrum, urban greenspace contributes to the food supply, job creation, tourism boost, property value increase and consumption reduction (Baycan-Levent \& Nijkamp, 2009; Chiesura, 2004; Fam et al., 2008). And in the environmental spectrum, 
urban greenspaces contribute to air filtration, rainwater infiltration, carbon storage, sequestration, cooling, and mitigation of heat islands (Cameron et al., 2012; De Ridder et al., 2004; Ramaiah \& Avtar, 2019). The paper has acknowledged many articles on the benefits or contributions of urban greenspaces. But it has combined BentonShort et al. (2017), and Wendel (2011)'s provided classification or benefits of urban greenspaces in the social, economic, and environmental spectrums (see figure 2) for providing a comprehensive understanding of the contributions of greenspaces and a foundation for accomplishing the research objective.

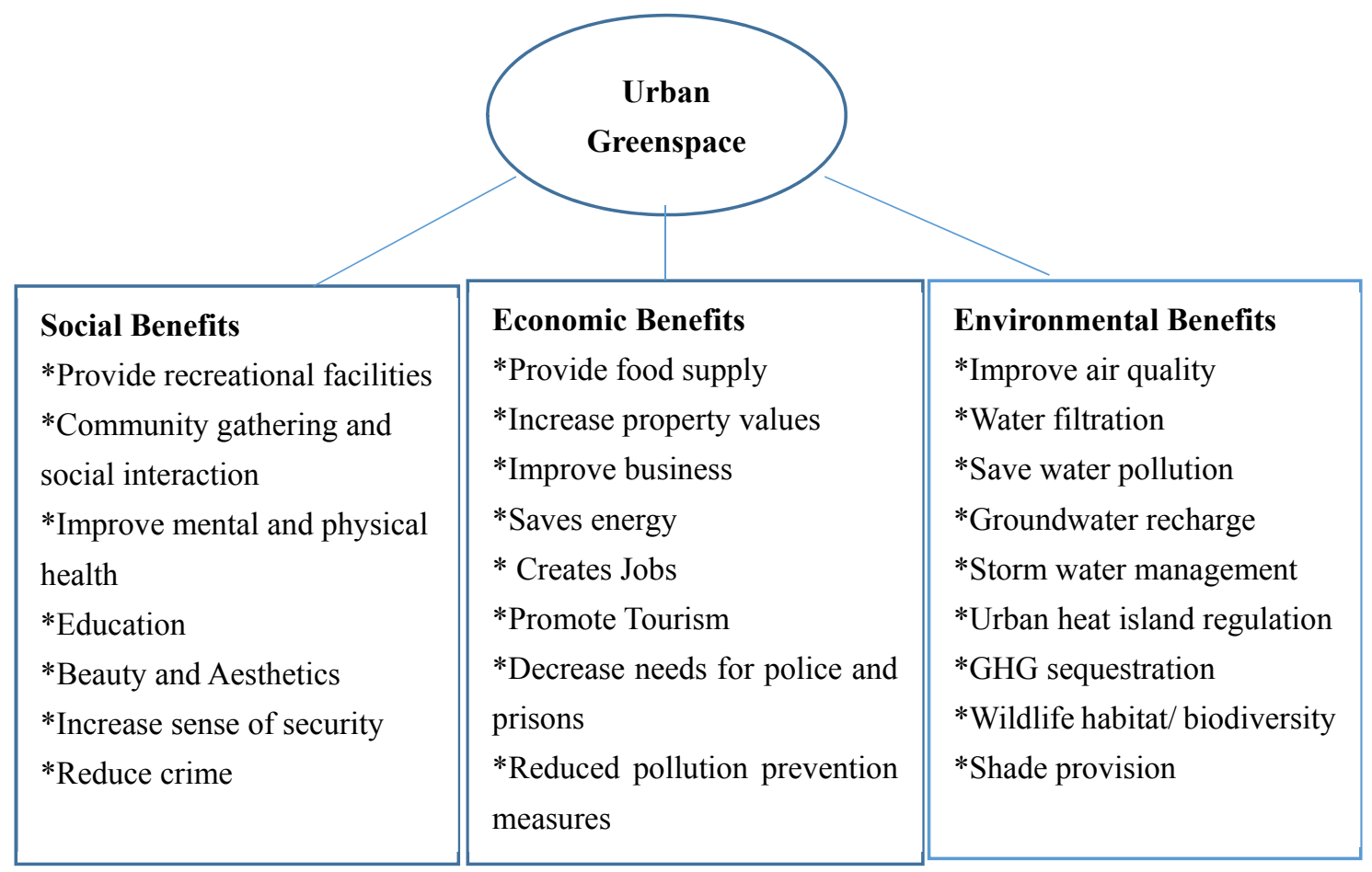

Figure 2. Benefits of urban greenspace

Source: Adopted by Authors and modified from Wendel (2011) and Benton-Short et al. (2017)

\subsection{Urban Greenspace and SDGs 2030 Linkages}

Sustainable Development Goals (SDGs) 2030 provides a shared blueprint to achieve a better and more sustainable future for all. In its vision, there are six universal objectives: i) to improve individual living conditions in the community, ii) to maintain food safety, iii) to maintain water safety, iv) to make clean energy universally accessible, v) to ensure ecosystems function healthily and productively, and vi) is to establish the necessary public administration for a sustainable community (UN, 2015). The main goals of these objectives are social development, environmental protection, and economic growth. For attaining these goals, SDGs 2030 is made up of 17 goals disaggregated into 169 targets and covers different aspects of social development, environmental protection, and economic growth. Among these targets, target 11.7: to provide universal access to safe, inclusive, and accessible, green, and public spaces, for women and children, older persons, and persons with disabilities by 2030 , is directly linked with urban greenspace and giving importance to provisioning adequate amount of urban greenspace for the wellbeing of urban citizens or social development particularly. Provisioning urban greenspaces not only contributes to social development but also contributes to environmental and economic development. Urban greenspaces contribute to social, environmental, and economic development on the one hand and SDGs' targets cover different aspects of social development, environmental protection, and economic growth on the other. This interconnection establishes a linkage between urban greenspaces and SDGs 2030. However, to understand the linkages more explicitly, the following section of the study brings examples and empirical evidence to depict how urban greenspaces contribute to different SDGs.

\subsubsection{Link with SDGs Goal 1 and 2}

Urban agricultural land or community garden supplies food and help to provide nutrition for urban residents, including children, pregnant mothers, and senior citizens. By providing food and nutrition, urban greenspaces 
contribute to ending poverty and hunger. For instance, in their study on Malaysia, Rezai, Shamsudin and Mohamed (2016) have found a positive association between obtaining a sufficient quantity of food and adequate diet through engagement in urban agriculture. Such contribution of urban agriculture is linked with goals 1 and 2 of SDGs: No Poverty and Zero Hunger. Urban agriculture also helps to prevent child malnutrition. For example, in the context of Kampala, Uganda, Maxwell, Levin and Csete (1998) have discovered that child nutrition status is significantly higher among the urban households that have farm. This contribution is particularly linked with SDGs target 2.2: by 2030 , end all forms of malnutrition, including achieving, by 2025 , the internationally agreed targets on stunting and wasting in children under five years of age, and address the nutritional needs of adolescent girls, pregnant and lactating women and older persons. Furthermore, Semi-natural greenspace or trees and dense vegetation protect urban areas especially coastal urban areas from wind and storm events (Cattell, Dines, Gesler \& Curtis, 2008) which is linked with SDGs target 1.5: build the resilience of the poor and those in vulnerable situations and reduce their exposure and vulnerability to climate-related extreme events and other economic, social and environmental shocks and disasters.

\subsubsection{Link with SDGs Goal 3, 6 and 7}

Amenity greenspaces or urban parks contribute to healthy living and wellbeing for all residents. Availability and exposure to greenspaces positively contribute to reducing mortality and maternal mortality rate as well. For example, Hu, Liebens and Ranga (2008) have observed a high level of stroke mortality in areas with lower exposure to greenspace in their study in Florida, USA. In their study, Maas et al. (2009) have also found that people with more greenspaces in a $1 \mathrm{~km}$ radius around their home had a lower annual prevalence rate of disease in the Netherlands. This relation is strong with children and the elderly. Urban heat-mortality relationships are also evident in an urban context for lack of urban greenspace. For example, Hajat and Kosatky (2010), in their study on heat-mortality relationships in cities, have found that the risk of mortality increases between one percent and three percent for every $10^{\circ} \mathrm{C}$ change in high temperature. Thus, the contribution of urban greenspaces is directly linked with SDGs target 3.1: To reduce the global maternal mortality ratio to less than 70 per 100,000 live births by 2030 . Amenity greenspaces also contribute to individuals' mental health by reducing depression and increasing happiness. Regarding this, the study by Cohen-Cline et al. (2015) has found a strong positive relationship between access to greenspaces and depression. Svendsen, Turkheimer and Duncan (2012) and Lwasa et al. (2014) also claim in their study about the positive relationship between exposure to greenspaces and happiness. Such contribution to mental health is linked with SDGs target 3.4: to reduce by one-third premature mortality from noncommunicable diseases through prevention and treatment and promote mental health and wellbeing by 2030 .

Irrespective of types, all urban greenspaces improve city air quality by filtering atmospheric particulates which helps reduce mortality. For example, Brauer, Reynolds and Hystad (2013), in their study on the relationship between air pollution and premature deaths in Canada, suggest that approximately 21,000 premature deaths are related to air pollution in Canada each year. Similarly, Curtis, Helmig, Baroch, Daly and Davis (2014) found that planting one million low-emitting tree species will prevent between 30,000 kilograms and 1.1 million kilograms volatile organic compounds (VOC) emissions. Along with air pollution control, greenspace contributes to ensuring availability and sustainable management of water. As urban greenspaces filter the runoff water from rain, improve water quality and recharge groundwater (Davern, Farrar, Kendal \& Giles-corti, 2017). Thus, the contribution of greenspaces to air quality and mortality is linked with SDGs target 3.9: by 2030, substantially reduce the number of deaths and illnesses from hazardous chemicals and air, water, and soil pollution and contamination. Urban greenspaces also contribute to urban water management. For example, research by $\mathrm{Li}$ and Bergen (2018) on the role of urban green infrastructure on urban water management systems in Singapore, Berlin, Melbourne, Tianjin, and Philadelphia, have found that all cities apply green infrastructure-based stormwater management solutions. Singapore applies reservoir and river parks for water supply, flood control, and recreation, Berlin applies riverbank filtration systems, Melbourne and Tianjin Eco-city irrigate public green spaces with non-conventional water to reduce potable water consumption. Philadelphia is transforming the impervious urban surfaces into greened acres for controlling combined sewer overflow. Such contributions of urban greenspaces are related to SDGs target 6.1 and 6.4: (6.1: by 2030, achieve universal and equitable access to safe and affordable drinking water for all, and 6.4: by 2030 , substantially increase water-use efficiency across all sectors and ensure sustainable withdrawals and supply of freshwater to address water scarcity and substantially reduce the number of people suffering from water scarcity). Furthermore, by managing freshwater, greenspaces also improve, maintain, and restore urban habitats and water-related ecosystems including mountains, forests, wetlands, rivers, aquifers, and lakes or biodiversity (Davern et al., 2017). Thus, such contribution to biodiversity is linked with SDGs target 6.6: To protect and restore water-related ecosystems, including mountains, forests, wetlands, rivers, aquifers, and lakes. Furthermore, urban greenspaces are the source of cooling to mitigate urban heat islands, save energy consumption and improve energy 
efficiency (Davern et al., 2017). For example, Sun and Chen (2017) reveal that losing $108.86 \mathrm{sq}$. km. of greenspace in Beijing increases land-surface temperature between $1.6{ }^{\circ} \mathrm{C}$ to $2.2{ }^{\circ} \mathrm{C}$., while $92.5 \mathrm{sq}$. $\mathrm{km}$. of greenspace expansion reduces the land-surface temperature between $-1.1{ }^{\circ} \mathrm{C}$ to $-0.67{ }^{\circ} \mathrm{C}$. Consequently, greenspaces contribute to energy-saving (Zhang, Xie, Gao \& Yang, 2014). Such contribution is allied with SDGs target 7.3: to double the global rate of improvement in energy efficiency by 2030.

\subsubsection{Link with SDGs Goal 8 and 11}

Greenspaces including amenity greenspace, functional greenspace, semi-natural greenspace, and liner greenspace contribute to employment generation and economic growth. For example, urban parks create job opportunities for gardeners and other service industries like tourism. Urban agriculture or forest provide opportunities for farmers, gardeners, carpenters, and joiners (Comstock et al., 2010). Along with these opportunities, greenspaces also create ancillary work opportunities and businesses that contribute to economic growth. For example, the maintenance of urban green infrastructure in Easter cape town, South Africa, has created 17429 jobs which receive approximately US\$37 million per year in total. The contribution to the economy establishes the linkage with SDGs goal 8: To Promote sustained, inclusive, and sustainable economic growth, full and productive employment, and decent work for all. Urban greenspaces also contribute to achieving an inclusive, safe, resilient, and sustainable human settlement. A study by Mitchell, Richardson, Shortt and Pearce (2015) have revealed that urban greenspace reduces gaps in mental wellbeing among socio-economic groups and improves their participation in decision-making which in turn helps to achieve SDGs target 11.3: Enhance inclusive and sustainable urbanization and capacity for participation, integrated and sustainable human settlement planning and management in all countries. Furthermore, urban greenspaces like city parks are part of city culture and heritage and managing these spaces contribute to the protection and safeguard of the world's culture and natural heritage (Dou et al., 2017; Henderson, 2013), which is linked with SGDs target 11.4: Strengthen efforts to protect and safeguard the world's cultural and natural heritage.

\subsubsection{Link with SDGs Goal 13 and 15}

Regardless of types, all urban greenspaces contribute to combating climate change and its impacts. For instance, Liu \& Shen (2014) confirm that urban greenspaces change air pollution and microclimate that directly contribute to climate change, associated with SDGs goal 13: Take urgent action to combat climate change and its impacts. In addition, urban greenspaces provide suitable shelter and nesting habitats for species and that help to protect and conserve the native species (Aronson et al., 2014; Shukuroglou \& McCarthy, 2006). Such contribution of urban greenspaces is linked with SDGs target 15.5: Taking urgent and significant action to reduce the degradation of natural habitats, halt the loss of biodiversity, and by 2020, protect and prevent the extinction of threatened or endangered species.

All the above evidence suggests that there are both implicit or explicit connections between urban greenspace and SDGs targets. Some associations are straight and strong, while others are supplementary and infirm. The study identifies 15 linkages (figure 3) where target 11.7 of SDGs explicitly focuses on the provision of urban greenspaces for the well-being of urban residents. The rest of the fourteen implicit linkages acknowledge how urban greenspaces can contribute to achieving SDGs targets. Thus, achieving SDGs target 11.7 is not a standalone success, it will work as a catalyst for achieving other SDGs targets. 


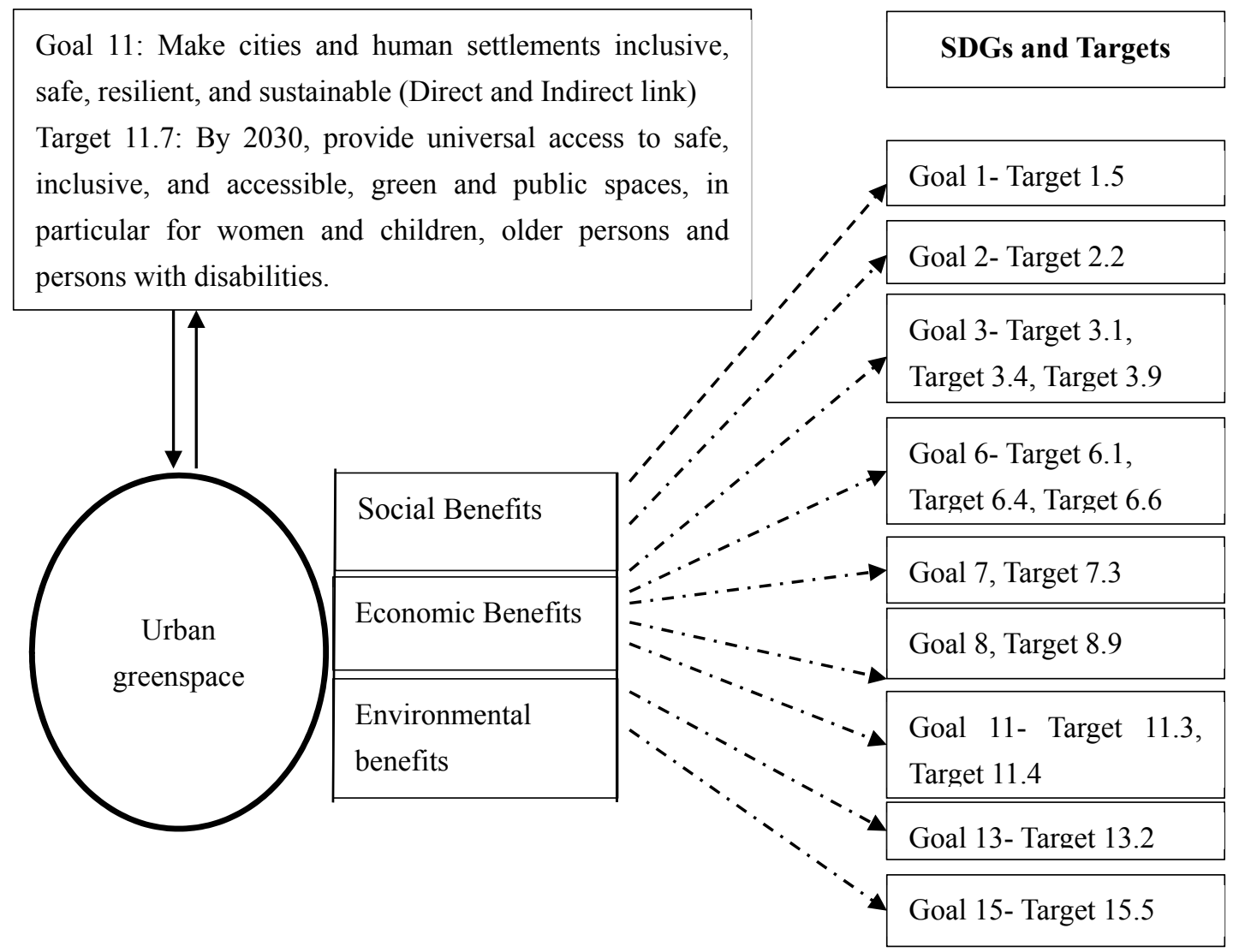

Figure 3. Urban greenspace and SDGs linkages

Source: Adopted by authors

\section{Conclusion}

Urban greenspaces have immense contributions to the social, economic, and environmental spectrums of sustainable development. And these three spectrums are the foundation of SDGs 2030. Thus, urban greenspaces have great potential for contributing and achieving SDGs 2030. However, an urban area is comprised of different types of greenspaces and their contributions differ for their size, quantity, quality, and functions. Therefore, their significance to the contribution of SDGs 2030 also varies. For example, an urban forest has a more significant positive impact for preventing urban heat islands or climate change than a public park. And a park has a greater positive impact on the health and mental wellbeing of urban residents than an urban forest. Thus, it is not possible to define which types of greenspaces have greater influence for achieving SDGs 2030. So, all forms of urban greenspaces need equal importance for their contribution. But often, cities provide importance to urban parks only and ignore other greenspaces, and even in many cities where there is intense development pressure, urban greenspaces are judged as an unproductive investment. However, in recent years, urban greenspaces development is receiving attention worldwide. International development authorities, government authorities, nongovernmental actors, and local communities are taking different initiatives for developing greenspaces in urban areas, for example, Food and Agriculture Organization [FAO] (2020) has launched Green Cities Initiative aiming at improving the livelihoods and wellbeing of urban and peri-urban populations in at least 100 cities around the world by increasing availability of greenspaces through the urban and peri-urban forest. C40, the network of mayors of nearly 100 world-leading cities, has signed C40's urban nature declaration and committed further significant investments in urban greenspaces to protect cities from the impacts of climate change and ensure everyone has access greenspaces (C40 Cities, 2022). The National New-Type Urbanization Plan (2014-2020) (NNUP) of China has reinforced the central state's commitment to fostering greener patterns of urban development (Zhang, Chung, \& Yin, 2020). The city of Melbourne has introduced an urban forest strategy from 2012-2032 to maintain the health and livability of Melbourne (City of Melbourne, 2012). However, though many developed cities have taken initiatives to develop urban greenspaces, developing and least-developed cities are struggling to prioritize urban greenspaces or environmental agendas over economic development agendas. Therefore, urban 
greenspaces in the global south are in decline or have less urban greenspaces coverage and accessibility than cities in the global north (Huang et al., 2021). Thus, realizing the significance of urban greenspaces for achieving SDGs 2030, least developed countries need to adopt strategies and actions for developing urban greenspaces.

\section{Acknowledgments}

We would like to acknowledge RMIT University, Australia for giving us the opportunity to do our Ph.D. study. Without this opportunity, we would not be able to access all the scholarly articles that we have used in this paper.

\section{References}

Akobeng, A. K. (2005). Understanding systematic reviews and meta-analysis. Archives of Disease in Childhood, 90(8), 845-848. https://doi.org/10.1136/adc.2005.071761

Ambrey, C., \& Fleming, C. (2014). Public Greenspace and Life Satisfaction in Urban Australia. Urban Studies, 51(6). https://doi.org/10.1177/0042098013494417

Aronson, M. F. J., La Sorte, F. A., Nilon, C. H., Katti, M., Goddard, M. A., Lepczyk, C. A., Warren, P. S., Williams, N. S. G., Cilliers, S., Clarkson, B., Dobbs, C., Dolan, R., Hedblom, M., Klotz, S., Kooijmans, J. L., Kühn, I., Macgregor-Fors, I., Mcdonnell, M., Mörtberg, U., ... Winter, M. (2014). A global analysis of the impacts of urbanization on bird and plant diversity reveals key anthropogenic drivers. Proceedings of the Royal Society B: Biological Sciences, 281(1780). https://doi.org/10.1098/rspb.2013.3330

Barbosa, O., Tratalos, J. A., Armsworth, P. R., Davies, R. G., Fuller, R. A., Johnson, P., \& Gaston, K. J. (2007). Who benefits from access to green space? A case study from Sheffield, UK. Landscape and Urban Planning, 83(2-3), 187-195. https://doi.org/10.1016/j.landurbplan.2007.04.004

Baycan-Levent, Tuzin, Leeuwen, E. van, Rodenburg, C., \& Nijkamp, P. (2002). Development and Management of Green Spaces in European Cities : 38th International Planning Congress on The Pulsar Effect Planning, 2126.

Baycan-Levent, Tüzin, \& Nijkamp, P. (2009). Planning and Management of Urban Green Spaces in Europe : Comparative Analysis. Urban Planning and Development, 135(March), 1-12. https://doi.org/10.1061/(asce)0733-9488(2009)135:1(1)

Baycan, T., Levent, T. B., Vreeker, R., \& Nijkamp, P. (2004). Multidimensional Evaluation of Urban Green Spaces : A Comparative Study on European Cities Multidimensional Evaluation of Urban Green Spaces: A Comparative Study on European Cities. Retrieved from https://www.researchgate.net/publication/4795787

Benton-Short, L., Keeley, M., \& Rowland, J. (2017). Green infrastructure, green space, and sustainable urbanism: geography's important role. Urban Geography, 00(00), 1-22. https://doi.org/10.1080/02723638.2017.1360105

Brauer, M., Reynolds, C., \& Hystad, P. (2013). Traffic-related air pollution and health in Canada. Canadian Medical Association Journal, 185(18), 1557-1558.

C40 Cities. (2022). Urban Nature Declaration. C40 Cities Climate Leadership Group, Inc. Retrieved from https://www.c40.org/declarations/urban-nature-declaration/

Cameron, R. W. F., Blanuša, T., Taylor, J. E., Salisbury, A., Halstead, A. J., Henricot, B., \& Thompson, K. (2012). The domestic garden - Its contribution to urban green infrastructure. Urban Forestry and Urban Greening, 11(2), 129-137. https://doi.org/10.1016/j.ufug.2012.01.002

Cattell, V., Dines, N., Gesler, W., \& Curtis, S. (2008). Mingling, observing, and lingering: Everyday public spaces and their implications for well-being and social relations. Health and Place, 14(3), 544-561. https://doi.org/10.1016/j.healthplace.2007.10.007

Chiesura, A. (2004). The role of urban parks for the sustainable city. Landscape and Urban Planning, 68(1), 129138. https://doi.org/10.1016/j.landurbplan.2003.08.003

City of Melbourne. (2012). Urban Forest Strategy: Making a great city greener 2012-2032. In City of Melbourne. Retrieved https://www.melbourne.vic.gov.au/Sustainability/UrbanForest/Documents/Urban_Forest_Strategy.pdf

Cohen-Cline, H., Turkheimer, E., \& Duncan, G. E. (2015). Access to green space, physical activity and mental health: A twin study. Journal of Epidemiology and Community Health, 69(6), 523-529. https://doi.org/10.1136/jech-2014-204667

Comstock, N., Miriam Dickinson, L., Marshall, J. A., Soobader, M. J., Turbin, M. S., Buchenau, M., \& Litt, J. S. 
(2010). Neighborhood attachment and its correlates: Exploring neighborhood conditions, collective efficacy, and gardening. Journal of Environmental Psychology, 30(4), 435-442. https://doi.org/10.1016/j.jenvp.2010.05.001

Curtis, A. J., Helmig, D., Baroch, C., Daly, R., \& Davis, S. (2014). Biogenic volatile organic compound emissions from nine tree species used in an urban tree-planting program. Atmospheric Environment, 95, 634-643. https://doi.org/10.1016/j.atmosenv.2014.06.035

Davern, M., Farrar, A., Kendal, D., \& Giles-corti, B. (2017). Quality Green Space Supporting Health, Wellbeing and Biodiversity: A Literature Review. March.

Davies, Z. G., Edmondson, J. L., Heinemeyer, A., Leake, J. R., \& Gaston, K. J. (2011). Mapping an urban ecosystem service: Quantifying above-ground carbon storage at a city-wide scale. Journal of Applied Ecology, 48(5), 1125-1134. https://doi.org/10.1111/j.1365-2664.2011.02021.x

De Ridder, K., Adamec, V., Bañuelos, A., Bruse, M., Bürger, M., Damsgaard, O., Dufek, J., Hirsch, J., Lefebre, F., Pérez-Lacorzana, J. M., Thierry, A., \& Weber, C. (2004). An integrated methodology to assess the benefits of urban green space. Science of the Total Environment, 334-335, 489-497. https://doi.org/10.1016/j.scitotenv.2004.04.054

Dou, Y., Zhen, L., Groot, R. De, Du, B., \& Yu, X. (2017). Assessing the importance of cultural ecosystem services in urban areas of Beijing municipality. Ecosystem Services, 24, 79-90. https://doi.org/10.1016/j.ecoser.2017.02.011

Dunnett, N., Swanwick, C., \& Woolley, H. (2002). Improving Urban Parks, Play Areas and Green Spaces. Department for Transport, Local Government and the Regions, 576 0, 217. https://doi.org/papers3://publication/uuid/A85EC5F0-75BD-4B3E-9D99-59967F595C4C

Fam, D., Mosley, E., Lopes, A., Mathieson, L., Morison, J., G., C., \& Futures, C. R. C. for I. (2008). Irrigation of urban green spaces: a review of the environmental, social and economic benefits. CRC for Irrigation Futures, 04, 1-47.

FAO. (2020). Green cities Initiative. Food and Agriculture Organization of the United Nations. Retrieved from https://www.fao.org/green-cities-initiative/en/

Fuwape, J. A., \& Onyekwelu, J. C. (2011). Urban Forest Development in West Africa: Benefits and Challenges. Journal of Biodiversity and Ecological Sciences, 1(1), 77-94.

Griffith, J. (2000). The Preservation of Community Green Space: Is Georgia Ready to Combat Sprawl with Smart Growth? Wake Forest Law Review, 35, 563.

Hajat, S., \& Kosatky, T. (2010). Heat-related mortality : a review and exploration of heterogeneity. Journal of Epidemiology and Community Health, 64(9), 753-760. https://doi.org/10.1136/jech.2009.087999

Hartig, T., Mitchell, R., de Vries, S., \& Frumkin, H. (2014). Nature and Health. Ssrn. https://doi.org/10.1146/annurev-publhealth-032013-182443

Henderson, J. C. (2013). Urban parks and green spaces in Singapore. Managing Leisure, 18(3), 213-225. https://doi.org/10.1080/13606719.2013.796181

Hu, Z., Liebens, J., \& Ranga, K. R. (2008). Linking stroke mortality with air pollution, income, and greenness in northwest Florida: An ecological geographical study. International Journal of Health Geographics, 7, 1-22. https://doi.org/10.1186/1476-072X-7-20

Huang, C., Yang, J., Clinton, N., Yu, L., Huang, H., Dronova, I., \& Jin, J. (2021). Mapping the maximum extents of urban green spaces in 1039 cities using dense satellite images. Environmental Research Letters, 16(6). https://doi.org/10.1088/1748-9326/ac03dc

Hunter, R. F., Christian, H., Veitch, J., Astell-Burt, T., Hipp, J. A., \& Schipperijn, J. (2015). The impact of interventions to promote physical activity in urban green space: A systematic review and recommendations for future research. Social Science and Medicine, 124, 246-256. https://doi.org/10.1016/j.socscimed.2014.11.051

Ikin, K., Beaty, R. M., Lindenmayer, D. B., Knight, E., Fischer, J., \& Manning, A. D. (2013). Pocket parks in a compact city: How do birds respond to increasing residential density? Landscape Ecology, 28(1), 45-56. https://doi.org/10.1007/s10980-012-9811-7

Jim, C. Y., \& Chen, S. S. (2003). Comprehensive greenspace planning based on landscape ecology principles in 
compact Nanjing city, China. Landscape and Urban Planning, 65(3), 95-116. https://doi.org/10.1016/S01692046(02)00244-X

Kabisch, N., \& Haase, D. (2014). Green justice or just green? Provision of urban green spaces in Berlin, Germany. Landscape and Urban Planning, 122, 129-139. https://doi.org/10.1016/j.landurbplan.2013.11.016

Kabisch, N., van den Bosch, M., \& Lafortezza, R. (2017). The health benefits of nature-based solutions to urbanization challenges for children and the elderly - A systematic review. Environmental Research, 159(August), 362-373. https://doi.org/10.1016/j.envres.2017.08.004

Knuiman, M. W., Christian, H. E., Divitini, M. L., Foster, S. A., Bull, F. C., Badland, H. M., \& Giles-Corti, B. (2014). A longitudinal analysis of the influence of the neighborhood built environment on walking for transportation: The RESIDE study. American Journal of Epidemiology, 180(5), 453-461. https://doi.org/10.1093/aje/kwu171

Kohout, M., \& Kopp, J. (2020). Green space ideas and practices in European cities. Journal of Environmental Planning and Management, 63(14), 2464-2483. https://doi.org/10.1080/09640568.2020.1716698

Kothencz, G., Kolcsár, R., Cabrera-Barona, P., \& Szilassi, P. (2017). Urban green space perception and its contribution to well-being. International Journal of Environmental Research and Public Health, 14(7). https://doi.org/10.3390/ijerph14070766

Lachowycz, K., \& Jones, A. P. (2013). Towards A Better Understanding Of The Relationship Between Greenspace And Health: Development Of A Theoretical Framework. Landscape and Urban Planning, 118, 62-69. https://doi.org/10.1016/j.landurbplan.2012.10.012

Li, L., \& Bergen, J. M. (2018). Green infrastructure for sustainable urban water management: Practices of five forerunner cities. Cities, 74(February 2017), 126-133. https://doi.org/10.1016/j.cities.2017.11.013

Liu, H. L., \& Shen, Y. S. (2014). The impact of green space changes on air pollution and microclimates: A case study of the taipei metropolitan area. Sustainability (Switzerland), 6(12), 8827-8855. https://doi.org/10.3390/su6128827

Low, S., Taplin, D., \& Scheld, S. (2009). Rethinking urban parks: Public space and cultural diversity. University of Texas Press.

Lwasa, S., Mugagga, F., Wahab, B., Simon, D., Connors, J., \& Griffith, C. (2014). Urban and peri-urban agriculture and forestry: Transcending poverty alleviation to climate change mitigation and adaptation. Urban Climate, 7, 92-106. https://doi.org/10.1016/j.uclim.2013.10.007

Maas, J., Verheij, R. A., De Vries, S., Spreeuwenberg, P., Schellevis, F. G., \& Groenewegen, P. P. (2009). Morbidity is related to a green living environment. Journal of Epidemiology and Community Health, 63(12), 967-973. https://doi.org/10.1136/jech.2008.079038

Maxwell, D., Levin, C., \& Csete, J. (1998). Does urban agriculture help prevent malnutrition? Evidence from Kampala. Food Policy, 23(5), 411-424. https://doi.org/10.1016/S0306-9192(98)00047-5

Mensah, C. A. (2014). Urban green spaces in Africa: Nature and challenges. International Journal of Ecosystem, 4(1), 1-11. https://doi.org/10.5923/j.ije.20140401.01

Mitchell, R. J., Richardson, E. A., Shortt, N. K., \& Pearce, J. R. (2015). Neighborhood Environments and Socioeconomic Inequalities in Mental Well-Being. American Journal of Preventive Medicine, 49(1), 80-84. https://doi.org/10.1016/j.amepre.2015.01.017

Mukherjee, M., \& Takara, K. (2018). Urban green space as a countermeasure to increasing urban risk and the UGS-3CC resilience framework. International Journal of Disaster Risk Reduction, 28(January), 854-861. https://doi.org/10.1016/j.ijdrr.2018.01.027

Ramaiah, M., \& Avtar, R. (2019). Urban Green Spaces and Their Need in Cities of Rapidly Urbanizing India: A Review. Urban Science, 3(3), 94. https://doi.org/10.3390/urbansci3030094

Rezai, G., Shamsudin, M. N., \& Mohamed, Z. (2016). Urban Agriculture: A Way Forward to Food and Nutrition Security in Malaysia. Procedia - Social and Behavioral Sciences, 216(October 2015), 39-45. https://doi.org/10.1016/j.sbspro.2015.12.006

Scottish Executive. (2001). Rethinking Open Space: Open Space Provision and Management - A Way Forward. https://doi.org/10.1049/iet-syb.2012.0042

Shukuroglou, P., \& McCarthy, M. A. (2006). Modelling the occurrence of rainbow lorikeets (Trichoglossus 
haematodus) in Melbourne. Austral Ecology, 31(2), 240-253. https://doi.org/10.1111/j.14429993.2006.01588.x

Sun, R., \& Chen, L. (2017). E ff ects of green space dynamics on urban heat islands : Mitigation and diversi fi cation. Ecosystem Services, 23(October 2016), 38-46. https://doi.org/10.1016/j.ecoser.2016.11.011

Svendsen, E., Northridge, M. E., \& Metcalf, S. S. (2012). Cities and the Environment (CATE) Integrating Grey and Green Infrastructure to Improve the Health and Well-being of Urban Populations Integrating Grey and Green Infrastructure to Improve the Health and Well-being of Urban Populations. Cities and the Environment, 5(1). https://doi.org/10.1086/529027

Swanwick, C., Dunnett, N., \& Woolley, H. (2003). Nature, role and value of green space in towns and cities: An overview. Built Environment, 29(2), 94-106. https://doi.org/10.2148/benv.29.2.94.54467

Tavernia, B. G., \& Reed, J. M. (2009). Spatial extent and habitat context influence the nature and strength of relationships between urbanization measures. Landscape and Urban Planning, 92(1), 47-52. https://doi.org/10.1016/j.landurbplan.2009.02.003

Taylor, L., \& Hochuli, D. F. (2017). Defining greenspace: Multiple uses across multiple disciplines. Landscape and Urban Planning, 158, 25-38. https://doi.org/10.1016/j.landurbplan.2016.09.024

United Nations. (2012). Meeting Coverage and Press Releases: Sectretary General Statement and Messages. Retrieved from https://www.un.org/press/en/2012/sgsm14249.doc.htm

United Nations. (2015). Transforming our world: the 2030 Agenda for sustainable Development (A/RES/70/1). Retrieved https://www.un.org/en/development/desa/population/migration/generalassembly/docs/globalcompact/A_RE S_70_1_E.pdf

Van Herzele, A., \& Wiederman, T. (2003). A Monitoring Tool for the Provision for Accessible and Attractive Green Spaces. Landscape and Urban Planning, 63(2), 109-126. https://doi.org/10.1016/S0169-2046(02)00192-5

Victor, L. (2008). Social Research Update Systematic reviewing. Review Literature And Arts Of The Americas, 54.

Wendel, H. E. W. (2011). An Examination of the Impacts of Urbanization on Green Space Access and Water Resources: A Developed and Developing World Perspective. University of South Florida. Retrieved from http://scholarcommons.usf.edu/etd/3413

Wilson, O., \& Hughes, O. (2011). Urban green space policy and discourse in England under new labour from 1997 to 2010. Planning Practice and Research, 26(2), 207-228. https://doi.org/10.1080/02697459.2011.560462

Woolley, H. (2003). Urban open spaces. Taylor and Francis.

Yusof, M. J. . (2012). The True Colours of Urban Green Spaces : Identifying and Assessing the Qualities of Green Spaces in Kuala Lumpur, Malaysia.

Zhang, B., Xie, G., Gao, J., \& Yang, Y. (2014). The cooling effect of urban green spaces as a contribution to energysaving and emission-reduction: A case study in Beijing, China. Building and Environment, 76, 37-43. https://doi.org/10.1016/j.buildenv.2014.03.003

Zhang, F., Chung, C. K. L., \& Yin, Z. (2020). Green infrastructure for China's new urbanisation: A case study of greenway development in Maanshan. Urban Studies, 57(3), 508-524. https://doi.org/10.1177/0042098018822965

\section{Copyrights}

Copyright for this article is retained by the author(s), with first publication rights granted to the journal.

This is an open-access article distributed under the terms and conditions of the Creative Commons Attribution license (http://creativecommons.org/licenses/by/4.0/). 